on the history of the invention are reproduced with illustrations. One of the most important is Ramsden's Royal Society paper of June 18, 1789, from which it appears that Chester Moor Hall had an achromatic object glass ground for him in 1732 or 1733 and that achromatic telescopes were made for him by the Strand optician J. Bird. The patent for the construction of such lenses from crown and flint glasses was taken out in 1758 by J. Dollond but no calculations were given, probably owing to the desire to keep the theory from other opticians. Klingenstierna worked out the theory, published it in the Transactions of the Swedish Academy in July 1760 and sent a copy to the Royal Society, which published it, although Dollond stated that it contained nothing which he had not done himself previously.

\section{Early Agricultural Tractors}

Mr. R. H. Clark, in the Engineer of February 2, under the title "Some Early Burrell Engines", recalls an almost forgotten chapter in the development of steam traction engines, built mainly for agricultural work. In 1846, James Boydell took out a patent for his "Endless Railway", and eight years afterwards patented improvements on it. His ideas were taken up by Charles Burrell and Co., a firm of country engineers established at Thetford in 1770 , and in 1856 the first road locomotive was constructed embodying the principle of the "Endless Railway". The general arrangement of the traction engine was much as that familiar a few years ago, but each of the wheels, instead of running on the surface of the road or field, ran on a series of flat shoes which in succession were brought into position by links and pins attached to the wheels. There were six shoes to each wheel.

This arrangement of shoes allowed the engine to move over the roughest roads and over soft and marshy ground. One of the illustrations shows an engine drawing four two-furrow ploughs. In 1857 a Boydell engine drew a load of nearly 44 tons from Bury St. Edmunds to Woolwich Arsenal at an average speed of 3.1 miles per hour. The cost of transport was $2 d$. per ton per mile against $6 d$. if horses had been employed. Boydell engines were apparently being built up to 1868 , when they were abandoned for engines with ordinary wheels.

\section{Prevention of Diphtheria by Immunization}

Aвоuт 60,000 cases of diphtheria, chiefly among children less than fifteen years of age, are notified annually in England and Wales, with some 3,000 deaths. Yet it has been shown, particularly in certain cities in Canada and the United States, that by artificial treatment or inamunization the disease may be practically banished. The Minister of Health has therefore issued an official memorandum urging that artificial immunization should be undertaken by county councils and sanitary authorities (Memo. $170 /$ Med. H.M. Stationery Office. 1d. net). It is suggested that the immunization should be undertaken as early in the child's life as is practicable and should form an integral part of the work of child welfare centres. The Memorandum gives technical details of the procedure and of the various forms of diphtheria prophylactic used, and of the need for Schick testing after treatment to ascertain whether this has been successful.

\section{Lice}

THE Minister of Health has recently issued a "Memorandum on the Louse and How to Deal With It" (Memo. 230/Med., 1940). Its publication comes at an opportune moment, when experience of evacuation has brought the louse problem into prominence. In the event of serious air raids large bodies of people may have to be removed to other districts. This, in itself, is liable to cause the spread of lice to localities, or among people, previously free from infestation. Ample powers are available under the Education and Public Health acts for the application of suitable control measures, and it is to be hoped that public medical officers and other officials will do all possible to reduce what has long been a standing menace to proper living conditions. Copies of the memorandum may be purchased directly from H.M. Stationery Office, or through a bookseller, price $2 d$. net.

\section{Vitamin E}

Reference was made in Nature of December 16 , 1939 , p. 1008 , to a solution of vitamin $\mathrm{E}$ now available commercially. Glaxo Laboratories Ltd. put on the market in 1933 capsules of wheat-germ oil extract (thirty times as potent in vitamin $\mathrm{E}$ as wheat-germ oil itself). The capsules were given the name 'Viteolin' in 1937. Viteolin was the preparation used by Currie and M'Gonigle in their published clinical trials which confirmed in Great Britain the value of vitamin $\mathbf{E}$ in the treatment of habitual abortion. With the availability of vitamin $\mathrm{E}$ as a chemical substance (tocopherol) each 'Viteolin' capsule has been standardized to contain the vitamin $\mathrm{E}$ potency of $6 \mathrm{mgm}$. of tocopherol, the potency clinically established as the desirable daily dosage.

\section{Institute of Physics and Freedom in Science}

THz Institute of Physics has sent the following letter signed by its president, Prof. W. L. Bragg, to the Polish Ambassador: "On behalf of the Board of the Institute of Physics I have to convey to you, and through you to your Government, the deep sorrow with which British physicists at home and overseas have heard of the forcible closure of the Institute of Physics in Warsaw, the dispersal of its eminent staff and the confiscation of its valuable equipment. Our sympathy goes out to our Polish colleagues in this interruption of their labours for the progress of our science, and in the tragic and unmerited hardships and perils which they are enduring. We look forward to the time, which we pray may not be far distant, when, restored to its former freedom, the Institute of Physics in Warsaw shall once again take its place among the great scientific institutions, and continue its work for the advancement of learning, and the welfare of mankind." 